\title{
COMMENTS
}

\section{CONCURRENT JURISDICTION AND ATTORNEY'S FEES: THE OBLIGATION OF STATE COURTS TO HEAR SEGTION 1983 GLAIMS}

\author{
KENNETH J. WILBUR ${ }^{\dagger}$
}

One of the more familiar characters in American literature is Herman Melville's Bartleby, the taciturn scrivener who disrupts his employer's law office by responding to any request to perform his duties with the enigmatic reply, "I would prefer not to." "1 In recent years, some state courts have indicated that they would "prefer not to" hear claims under 42 U.S.C. $\S 1983$ (1982) that seek an award of attorney's fees under the Givil Rights Attorney's Fee Awards Act of 1976 (section 1988). ${ }^{2}$

In the past, state courts' reluctance to hear section 1983 claims did not seriously affect parties attempting to redress violations of federal rights by state officials, since federal courts were the preferred forum for such suits. ${ }^{3}$ In the aftermath of Pennhurst State School $\&$ Hospital v. Halderman, ${ }^{4}$ however, the need to resort to state courts as the forum for federal as well as state claims has heightened the significance of determining whether state courts are obligated to hear section 1983 actions. Although the Supreme Court held that section 1983 claims may be brought in state courts, ${ }^{8}$ it has not defined clearly the circumstances, if any, under which a state court may properly refuse to hear a section 1983 suit. There is some evidence that state courts will conclude that

† B.A. 1984, Lehigh University; J.D. Candidate 1987, University of Pennsylvania.

1 Melville, Bartleby, The Scrivener, in The Norton ANTHology of SHORT Frction 991, 993 (R. Cassill 2d ed. 1981).

2 Pub. L. No. 94-559, 90 Stat. 2641 (codified at 42 U.S.C. $\S 1988$ (1982)).

3 See Nowak, The Scope of Congressional Power to Create Causes of Action Against State Governments and the History of the Eleventh and Fourteenth Amendments, 75 Colum. L. REv. 1413, 1443-44 (1975) (describing lack of federal jurisdiction as a drawback in suits against a state).

4465 U.S. 89 (1984). In Pennhurst, the Supreme Court held that the eleventh amendment prohibited federal courts from exercising pendent jurisdiction over suits seeking to enjoin state officials from violating state law. See infra text accompanying notes 18-30.

- See Martinez v. California, 444 U.S. 277, 283-85 (1980). 
the Court's failure to mandate state jurisdiction leaves state judges with the discretion to refuse to hear section 1983 claims. ${ }^{6}$ This Comment argues that no such discretion exists.

Part I surveys the procedural foundations of section 1983 suits and examines the impact of the Pennhurst decision on litigation of federal civil rights claims. Part II demonstrates that more than a century of judicial interpretation of the supremacy clause ${ }^{7}$ obligates state courts to hear section 1983 claims and compels them to grant the remedies, including attorney's fees, provided in section 1988. Part III argues that state courts cannot justify refusal to hear suits under section 1983 on the basis of sovereign immunity or any other constitutional principle, even in cases which could result in an attorney's fee award from a state treasury pursuant to section 1988.

\section{Section 1983 and the Pennhurst Problem}

To illustrate the elements involved in a suit under section 1983, assume that a single father sues to enjoin his exclusion from a state program authorizing financial assistance for working mothers. Arguing that the exclusion would constitute a violation of his right to equal protection of the laws granted by the fourteenth amendment, ${ }^{8}$ the father would have a claim under section 1983 against the state official administering the program. The cause of action under section 1983, originally created by the Civil Rights Act of $1871,{ }^{\circ}$ allows suits in law and equity against any persons, including state and local government officials, who violate federally guaranteed rights "under color of" state law. ${ }^{10}$ In addition, as a result of congressional recognition that, unlike most federal civil rights acts, section 1983 and its related sections do not

- See Spencer v. South Carolina Tax Comm'n, 281 S.C. 492, 496-97, 316 S.E.2d 386, 388-89 (1984), affd, 105 S. Ct. 1859 (1985) (per curiam); see also Brown v. Hornbeck, 54 Md. App. 404, 413, 458 A.2d 900, 904 (1983) (declining to address issue whether the court was obligated to hear section 1983 claim).

7 U.S. ConST. art. VI, cl. 2.

s In Weinberger v. Wiesenfeld, 420 U.S. 636, 643 (1975), a Social Security provision, 42 U.S.C. $\S 402(\mathrm{~g})(1982)$, that provided survivor's benefits to widows but not widowers was found to violate "the right to equal protection secured by the Fifth Amendment."

${ }^{8}$ Ch. 22, 17 Stat. 13 (1871) (codified as amended at 42 U.S.C. $\S 1983$ (1982)).

1042 U.S.C. $\S 1983$ (1982) states:

Every person who, under color of any statute, ordinance, regulation, custom, or usage, of any State . . . subjects, or causes to be subjected, any citizen of the United States . . . to the deprivation of any rights, privileges, or immunities secured by the Constitution and laws, shall be liable to the party injured in an action at law, suit in equity, or other proper proceeding for redress. 
contain attorney's fee provisions, ${ }^{11}$ section 1988 was amended to authorize courts to award a reasonable attorney's fee to the prevailing party in a suit to enforce section $1983 .{ }^{12}$ Congress justified fee shifting under section 1988 as follows:

In many cases arising under our civil rights laws, the citizen who must sue to enforce the law has little or no money with which to hire a lawyer. If private citizens are to be able to assert their civil rights, and if those who violate the Nation's fundamental laws are not to proceed with impunity, the citizens must have the opportunity to recover what it costs them to vindicate these rights in court. ${ }^{13}$

Frequently the state action that is the subject of a section 1983 suit is also alleged to violate state law. For example, assume that in the hypothetical suit discussed above the state's own constitution expressly prohibits the distribution of benefits on the basis of sex. The plaintiff would then have a strong argument that his exclusion from the program infringes his rights under the state constitution. However, unless state law also contained an attorney's fee provision, the plaintiff, if forced to an election of remedies, would most likely seek relief through a section 1983 suit, which could yield an award of attorney's fees.

Prior to the Supreme Court's decision in Pennhurst State School \& Hospital $v$. Halderman, ${ }^{14}$ there was no need for a plaintiff to forsake a state law claim while pursuing the federal claim in federal court. Under the doctrine of pendent jurisdiction, a state law claim arising under the same "nucleus of operative fact[s]" as those of the section 1983 claim could be decided by a federal court. ${ }^{15}$ As a result, even if

11 See S. ReP. No. 1011, 94th Cong., 2d Sess. 3-5, reprinted in 1976 U.S. Code Cong. \& AD. NEws 5908, 5910-13.

12 It should be noted that the amendment to 42 U.S.C. $\S 1988$ also provides for attorney's fees in actions under 42 U.S.C. $\$ \S 1981,1982,1985$ and 1986. See Civil Rights Attorney's Fee Awards Act of 1976, Pub. L. No. 94-559, 90 Stat. 2641 (codified as an amendment to 42 U.S.C. $§ 1988$ (1982)). Attorney's fee provisions are especially appropriate for suits under section 1983 since a state cannot be held liable for damages, see Edelman v. Jordan, 415 U.S. 651, 663 (1974), and since state officials enjoy a qualified good faith immunity, see, e.g., Fair Assessment in Real Estate Ass'n v. McNary, 454 U.S. 100, 115 (1981). These factors make the prospect of a damage award too unlikely to provide adequate monetary incentive for an attorney to represent a client in a section 1983 action.

is S. ReP. No. 1011, 94th Cong., 2d Sess. 2, reprinted in 1976 U.S. Cone Cong. \& AD. News 5908, 5910.

14465 U.S. 89 (1984).

15 See United Mine Workers v. Gibbs, 383 U.S. 715, 727 (1966). Congress anticipated that plaintiffs in section 1983 suits would join pendent state claims when it passed the Civil Rights Attorney's Fee Awards Act. See H.R. REP. No. 1558, 94th Cong., 2d Sess. 4 n.7, reprinted in 1976 U.S. Code Cong. \& AD. News 5908, 5912. 
the plaintiff failed to prevail on the section 1983 claim, relief could be obtained under the state law claim without incurring the expense of litigating a second lawsuit in state court.

In addition to allowing plaintiffs to join state and federal claims in a federal forum, pendent jurisdiction provided federal courts with a way to avoid deciding cases on constitutional grounds. Section 1983 litigation frequently involves constitutional questions, which American courts prefer to avoid whenever possible. ${ }^{16}$ By granting relief under pendent state claims, federal courts avoid resolution of cases on constitutional grounds. A decision on state grounds alone, however, would appear to eliminate the basis for an attorney's fee award, since section 1988 authorizes fee awards only in suits to enforce federal claims. Congress recognized this problem when section 1988 was amended. The legislative history indicates that Congress anticipated the approach subsequently adopted by the Court, which has held that as long as a plaintiff states a substantial claim under section $1983,{ }^{17}$ a fee award is justified in cases where the plaintiff eventually prevails on a state law claim that arises out of the same "common nucleus of operative fact[s]" as the section 1983 claim. $^{18}$

In 1984, however, the Supreme Court in effect discouraged the bringing of section 1983 claims in federal courts with its decision in Pennhurst. The case involved a suit by patients in a state institution

${ }^{16}$ See, e.g., Ashwander v. Tennessee Valley Auth., 297 U.S. 288, 347 (1936) (Brandeis, J., concurring) ("The Court will not pass upon a constitutional question . . . if there is also present some other ground upon which the case may be disposed of."); see also Pennhurst State School \& Hosp. v. Halderman, 465 U.S. 89, 159 (Stevens, J., dissenting) (citing Brandeis' opinion in Ashwander).

${ }_{17}$ Maher v. Gagne, 448 U.S. 122, 133 n.15 (1980). The substantiality test in Maher is derived from the Supreme Court's decisions in Hagans v. Levine, 415 U.S. 528 (1974), and United Mine Workers v. Gibbs, 383 U.S. 715 (1966).

is See Maher v. Gagne, 448 U.S. 122, 132 n.15. In addition to the substantiality test, two other procedural rubrics increase the probability that parties asserting their rights under section 1983 will be able to recover attorney's fees. First, reflecting Congress's concern that it would be counterproductive to force a party able to obtain relief through settlement to proceed to final judgment merely to obtain attorney's fees, see $\mathrm{S}$. REP. No. 1011, 94th Cong., 2d Sess. 5, reprinted in 1976 U.S. CodE ConG. \& AD. NEws 5908, 5912, courts, to encourage settlement whenever possible, have adopted a standard of considering a plaintiff to have prevailed in a section 1983 suit. If a significant issue is resolved such that the plaintiff has achieved some benefit through litigation, the plaintiff is entitled to attorney's fees. See, e.g., Bonnes v. Long, 599 F.2d 1316, 1318 (4th Cir. 1979).

Second, although section 1988 allows the court, at its discretion, to award the prevailing party reasonable attorney's fees as part of costs, the section also purports to encourage the awarding of attorney's fees. Congress intended that the party seeking to enforce rights under section 1983, if successful, "should ordinarily recover an attorney's fee unless special circumstances would render such an award unjust." "S. REP. No. 1011, 94th Cong., 2d Sess. 4, reprinted in 1976 U.S. Code Cong. \& AD. NEws 5908, 5912 (quoting Newman v. Piggie Park Enters., 390 U.S. 400, 402 (1968)). 
for the mentally retarded who alleged that their confinement in the facility violated the eighth and fourteenth amendments, federal statutory law, ${ }^{18}$ and state law. ${ }^{20}$ While the trial court found that plaintiffs were entitled to relief on several grounds, including the Pennsylvania Mental Health and Mental Retardation Act, ${ }^{21}$ the Court of Appeals for the Third Circuit, in affirming, relied primarily on the federal Developmentally Disabled Assistance and Bill of Rights Act. ${ }^{22}$ The Supreme Court reversed, concluding that the federal statute relied upon by the Third Circuit did not create any substantive rights, and remanded for reconsideration of plaintiffs' state law claim and other federal claims, which had been addressed by the district court but not by the circuit court. ${ }^{23}$ On remand, the court of appeals affirmed its judgment, basing its decision on the Pennsylvania Mental Health and Mental Retardation Act. ${ }^{24}$ The state appealed on the grounds that a holding in federal court based on the Pennsylvania statute was prohibited by the eleventh amendment.

The Supreme Court agreed with the state's reasoning. ${ }^{25}$ Noting that the eleventh amendment is a jurisdictional bar to suits brought in federal court against a state, it found that the district court did not have the power to grant relief under the Pennsylvania statute. ${ }^{26}$ The Court recognized that under Ex parte Young ${ }^{27}$ a suit challenging the constitutionality of a state official's action does not constitute a suit against the state, but refused to extend the Young "fiction" to a state official's violation of state law. ${ }^{28}$ Writing for the majority, Justice Powell observed

19 The plaintiffs in Pennhurst alleged violations of the Rehabilitation Act of 1973, 29 U.S.C. $\S 794$ (1982), and the Developmentally Disabled Assistance and Bill of Rights Act, 42 U.S.C. $\S \S 6001-6081$ (1982). See Pennhurst, 465 U.S. at 92.

20 The alleged violations of state law in Pennhurst involved the Pennsylvania Mental Health and Mental Retardation Act of 1966, PA. STAT. ANN. tit. 50, $\$ \S 4101$ 4704 (Purdon 1969). See Pennhurst, 465 U.S. at 92.

${ }_{21}$ See Halderman v. Pennhurst State School \& Hosp., 446 F. Supp. 1295, $1322-$ 23 (E.D. Pa. 1977), aff'd in part, rev'd in part, 612 F.2d 84 (3d Cir. 1979) (en banc), rev'd, 451 U.S. 1 (1981).

${ }_{22}$ See Halderman v. Pennhurst State School \& Hosp., 612 F.2d 84, 95-103 (3d Cir. 1979) (en banc), rev'd, 451 U.S. 1 (1981).

${ }^{23}$ See Pennhurst State School \& Hosp. v. Halderman, 451 U.S. 1, 18, 30-31 (1981).

${ }^{24}$ See Halderman v. Pennhurst State School \& Hosp., 673 F.2d 647, 651-54 (3d Cir. 1982), rev'd, 465 U.S. 89 (1984).

${ }^{28}$ See Pennhurst, 465 U.S. at 97.

${ }^{28}$ See id. at 124-25.

27209 U.S. 123 (1908). In Ex parte Young, the Court concluded that the eleventh amendment did not prevent federal courts from enjoining enforcement of unconstitutional state statutes. The Court reasoned that an unconstitutional state law is void, so that the officer seeking to enforce the law is "stripped of his official or representative character." Id. at 160.

28 See Pennhurst, 465 U.S. at 105-06. 
that "it is difficult to think of a greater intrusion on state sovereignty than when a federal court instructs state officials on how to conform their conduct to state law."29 Since such a suit would not come within the Young exception to state sovereign immunity in federal court, the Court held that the eleventh amendment barred from federal court a claim alleging violation of state law, even when pendent to a federal claim properly before a federal court. ${ }^{30}$

While Pennhurst did not involve a suit under section 1983, the decision affects litigants attempting to assert their rights under that statute. Plaintiffs who claim relief against a state official under both state law and section 1983 can no longer bring a single action in federal court. Pennhurst places many parties in the difficult position of having to litigate two suits: one in federal court under section 1983 (which would include a claim for attorney's fees), and, if the plaintiff does not obtain satisfactory relief in federal court, a second in state court under state law. Furthermore, lacking the option of deciding cases on pendent state law claims, federal courts in section 1983 actions often will reach the constitutional merits of cases that otherwise might be decided on state statutory grounds.

Plaintiffs could mitigate most problems posed by the Pennhurst decision by bringing their section 1983 actions with their state law actions in state courts. State courts, however, may resist enforcing the rights and granting the remedies, including fee awards, provided by the federal statute when the federal statute conflicts with the rights and remedies provided by state law. This Comment will attempt to show that a state court cannot refuse to enforce the provisions of section 1983 and section 1988 when it exercises jurisdiction over a state law action arising out of the same fact situation.

\section{State Courts' Obligation to Hear Section 1983 Glaims}

At first glance it might seem peculiar to advocate state courts as a forum for the protection of federal rights, but the supremacy clause compels state courts to protect the rights granted by the Constitution and laws of the United States. ${ }^{31}$ Before a state court can be required to hear a section 1983 claim, concurrent jurisdiction under federal law and jurisdiction over the parties and subject matter of the suit must

29 Id. at 106.

so See id. at 121. The Supreme Court remanded to the Court of Appeals for the Third Circuit to determine whether relief could be granted on other grounds. See id. at 124-25.

${ }^{31}$ See infra text accompanying notes 32-51. 
exist. This section will argue that once these jurisdictional elements are established, conflicts with state substantive or remedial law do not justify a state court's refusal to protect the rights and enforce the remedies provided by section 1983 and section 1988.

\section{A. Concurrent State Jurisdiction Over Section 1983 Claims.}

As long ago as 1876 , in Claflin v. Houseman, ${ }^{32}$ the Supreme Court held that a plaintiff could pursue a claim brought under a federal statute in state court. Justice Bradley spoke for a unanimous court:

Every citizen of a state is a subject of two distinct sovereignties, having concurrent jurisdiction in the State,-concurrent as to place and persons, though distinct as to subject-matter. Legal or equitable rights, acquired under either system of laws, may be enforced in any court of either sovereignty competent to hear and determine such kind of rights and not restrained by its constitution in the exercise of such jurisdiction. ${ }^{33}$

The Court suggested in Claflin that the supremacy clause, which binds state judges to recognize and support federal law, also compels them to hear federal claims in state courts:

The fact that a State court derives its existence and functions from the State laws is no reason why it should not afford relief; because it is subject also to the laws of the United States, and is just as much bound to recognize these as operative within the State as it is to recognize the State laws. ${ }^{34}$

In the Second Employers' Liability Cases, ${ }^{35}$ the Court clarified the obligation of state courts to exercise jurisdiction over federal claims by holding that state courts must provide a forum for actions arising under the Federal Employers Liability Act. ${ }^{36}$ The defendant had argued that the state court need not provide a forum for claims arising under the act, since the act conflicted with Connecticut law. ${ }^{37}$ The Court found that a state court has a duty "when its ordinary jurisdiction as prescribed by local laws is appropriate to the occasion and is invoked in conformity with those laws, to take cognizance of an action to enforce a

\footnotetext{
3293 U.S. 130 (1876).

ss Id. at 136 .

34 Id. at 137.

ss 223 U.S. 1 (1912).

se See id. at 56-59.

${ }^{37}$ See id. at $15-16,57$.
} 
right of civil recovery arising under the act of Congress."38 In Testa $v$. $\mathrm{Katt}_{2}{ }^{39}$ the Court, following the Second Employers' Liability Cases, decided that a state court must address a federal claim when the court has jurisdiction to adjudicate the same type of claim under state law. ${ }^{\mathbf{4 0}}$

Not every congressional act can be enforced in state courts; Congress frequently has exercised the power to confer exclusive jurisdiction upon federal courts. ${ }^{41}$ However, absent a finding of congressional intent to prevent state courts from hearing a federally created claim, state courts have concurrent jurisdiction over the federal claim. For example, in Charles Dowd Box Co. v. Courtney, ${ }^{42}$ the Supreme Court interpreted section 301(e) of the Labor Management Relations Act, ${ }^{43}$ which states that suits "may be brought in any district court of the United States," as permitting concurrent state jurisdiction, since Congress cast the right to bring suit in federal court in permissive rather than mandatory language. ${ }^{44}$ Accordingly, with respect to a statute that expressly provided for concurrent state jurisdiction, the Court recognized that the statute, rather than creating state court jurisdiction, merely recognized that state courts already possessed jurisdiction. ${ }^{45}$

Although section 1983 contains no provisions regarding jurisdiction, the relevant jurisdictional statute, 28 U.S.C. $\S 1343(\mathrm{a})(3),{ }^{46}$ provides for original, but not exclusive, federal court jurisdiction. Because section 1983 does not evidence an intent to exclude state court jurisdiction, the Dowd analysis suggests that state courts have concurrent jurisdiction to hear claims under section 1983. In several state courts, it has been argued that Congress intended to create exclusive federal jurisdiction under the Civil Rights Act of $1871,{ }^{47}$ the statute that preceded

38 Id. at 56-57.

39 330 U.S. 386 (1947).

10 Id. at 394.

41 See, e.g., L. Loss, Fundamentals of Securities Regulation 1016 \& n.4 (1983) (noting that, unlike most federal securities statutes, the Securities Exchange Act provides for exclusive jurisdiction in federal courts).

42368 U.S. 502 (1962).

1329 U.S.C. \& 185(a) (1982).

14 See Dowd, 368 U.S. at 506-08.

45 See Second Employers' Liab. Cases, 223 U.S. at 56.

428 U.S.C. $\S 1343$ (1982) states:

(a) The district courts shall have original jurisdiction of any civil action authorized by law to be commenced by any person: . . . (3) To redress the deprivation, under color of any State law, statute, ordinance, regulation, custom or usage, of any right, privilege or immunity secured by the Constitution of the United States or by any Act of Congress providing for equal rights of citizens or of all persons within the jurisdiction of the United States.

17 See Terry v. Kolski, 78 Wis. 2 d 475, 502-04, 254 N.W.2d 704, 715-16 (1977) (Hansen, J., dissenting) (arguing that since the Civil Rights Act of 1871 had its own 
section 1983. The Tennessee Supreme Court held, in Chamberlain v. Brown, that state courts are barred from hearing section 1983 claims. $^{48}$ Other state courts, however, have not found the reasoning in Chamberlain persuasive and have exercised jurisdiction over section 1983 suits. $^{49}$ In 1980, instead of following Chamberlain, the United States Supreme Court rejected an argument that jurisdiction to hear section 1983 suits rests exclusively with federal courts. ${ }^{50}$ State courts cannot rely on Chamberlain in refusing to hear section 1983 suits; the assertion that state courts are barred from entertaining claims under section 1983 is no longer plausible. ${ }^{\text {s1 }}$

\section{B. Discretionary Grounds for Refusing Jurisdiction Over Section 1983 Claims}

State courts that refuse to hear claims under section 1983 justify their discretion on the grounds that the Supreme Court, in Martinez v. California ${ }^{52}$ did not hold that state courts are obligated to hear such claims. ${ }^{53}$ Although the Court in Martinez explicitly refrained from holding that state courts must hear section 1983 claims, it qualified its position by noting, "[W]here the same type of claim, if arising under state law, would be enforced in the state courts, the state courts are

jurisdictional section that provided for exclusive federal jurisdiction, the "original jurisdiction" language in $\S 1343(\mathrm{a})(3)$ is the result of the clerical process of separating the substantive and jurisdictional provisions of the act in the Revised Statutes of 1874 and codifying the provisions in different titles of the United States Code, and is not attributable to congressional intent to allow concurrent state jurisdiction). But see id. at 488 90,254 N.W.2d at 708-09 (rejecting Justice Hansen's argument on the grounds that since the Revised Statutes of 1874 were intended to repeal all prior public acts, the provisions of the 1874 act, which are substantially identical to $\S 1343(\mathrm{a})(3)$, determine whether concurrent jurisdiction exists.

${ }^{48} 223$ Tenn. 25, 35, 442 S.W.2d 248, 252 (1969). In rejecting concurrent jurisdiction of section 1983 claims, the Tennessee Supreme Court analyzed the historical motivation behind the enactment of what has become 42 U.S.C. $\S 1983$. Relying on Monroe v. Pape, 365 U.S. 167, 171-87 (1961), in which the Supreme Court discussed the legislative history of the Civil Rights Act of 1871, the court reasoned that since the Civil Rights Act purported to provide access to federal courts to litigants whose rights might be jeopardized by bias or neglect in state courts, "[i]t would be illogical indeed to hold that a State court should enforce, or is required to enforce, an alleged cause of action which owes its very existence to congressional recognition of reluctance or refusal of State courts to act." Chamberlain, 223 Tenn. at 35, 442 S.W.2d at 252.

${ }^{49}$ See Kristensen v. Strinden, 343 N.W.2d 67, 70 (N.D. 1983) ("[E]very state court that has considered the Chamberlain decision has rejected its reasoning in favor of exercising jurisdiction in $\S 1983$ actions."); Terry, 78 Wis. $2 d$ at 481,254 N.W.2d at 711 (citing cases rejecting the reasoning in Chamberlain).

so Maine v. Thiboutot, 448 U.S. 1, 3 n.1 (1980):

s1 See id.; Martinez v. California, 444 U.S. 277, 283 n.7 (1980).

62444 U.S. 277 (1980).

ss See supra text accompanying note 5. 
generally not free to refuse enforcement of the federal claim."

The Court supported this proposition by citing Testa $v$. Katt. ${ }^{55}$ Testa established that a state court cannot refuse to hear a federal claim over which it has concurrent jurisdiction if it would hear the same type of claim arising under state law. ${ }^{\mathbf{5}}$ The state court must offer a forum for the federal claim, regardless of whether state law conflicts with the federal law being litigated. The Court noted in Second Employers' Liability Cases,

The suggestion that the act of Congress is not in harmony with the policy of the State, and therefore that the courts of the State are free to decline jurisdiction, is quite inadmissible, because it presupposes what in legal contemplation does not exist. . . . Congress, in the exertion of the power confided to it by the Constitution . . . spoke for all the people and all the States, and thereby established a policy for all. That policy is as much the policy of [the state] as if the act had emanated from its own legislature, and should be respected accordingly in the courts of the State. ${ }^{\mathbf{6 7}}$

The invocation of Testa by the Court in Martinez suggests that a state court's discretion to refuse to hear section 1983 claims is no greater than its discretion to decline jurisdiction over other federal claims.

With few exceptions, a state court must entertain a federal claim over which it has concurrent jurisdiction. The decision in Second Employers' Liability Cases demonstrates that state courts cannot refuse jurisdiction over federal claims because of conflict with state substantive law. ${ }^{58}$ Even when the federal suit appears to be barred by a local rule of procedure, a state court can still be compelled to adjudicate. For example, in McKnett v. St. Louis $\mathcal{E}$ San Francisco Railway, ${ }^{58}$ Alabama refused jurisdiction over a claim under the Federal Employers Liability Act (FELA) on the ground that an Alabama statute provided for state court jurisdiction only over claims involving common law or the statutes of another state. ${ }^{60}$ Since the claim invoked neither the common law nor a statute of another state, Alabama argued that its local procedural

s4 Martinez, 444 U.S. at 283-84 n.7 (citing Testa v. Katt, 330 U.S. 386, 394 (1947)).

SB 330 U.S. 386 (1947).

so Testa, 330 U.S. at 394.

sz Second Employers' Liab. Cases, 223 U.S. at 57.

s8 Id.

s9 292 U.S. 230 (1934).

${ }^{60} \mathrm{See}$ id. at 231-32. 
rules prevented an Alabama state court from hearing the federal claim. The Supreme Court found the Alabama statute unconstitutional as applied; a state may not discriminate against a claim "solely because the suit is brought under a federal law."

Dice v. Akron, Canton, $\mathcal{E}$ Youngstown Railroad ${ }^{\mathbf{6 2}}$ exemplifies the extent to which state courts are compelled to hear federal claims. In Dice, the Supreme Court reversed the Ohio state court decision, which deprived a plaintiff in a case under the Federal Employers Liability Act of the right under the statute to have all questions of fact submitted to the jury. ${ }^{63}$ Ohio law requires judges to decide the existence of certain types of fraud. ${ }^{64}$ However, the Supreme Court found that under the FELA:

"The right to trial by jury is . . . part and parcel of the remedy afforded railroad workers under the Employer Liability Act." . . . It follows that the right to trial by jury is too substantial a part of the rights accorded by the Act to permit it to be classified as a mere "local rule of procedure" for denial in the manner that Ohio has here used. ${ }^{65}$

The few cases in which the Supreme Court has upheld a state court's decision not to hear a claim arising under a federal statute involved situations where the courts would have refused to hear the plaintiffs' claims even if they had been brought under state law. In Douglas v. New York, New Haven $\mathcal{E}$ Hartford Railroad, ${ }^{\mathbf{6}}$ the Court upheld a New York court's refusal to adjudicate a claim under the FELA. The substantive and remedial provisions of the act were not at issue; instead, the New York court claimed that it did not have to provide a forum for a nonresident plaintiff suing a foreign corporation with regard to events not occurring. in New York. ${ }^{67}$ A New York statute, intended to afford the state's courts some measure of docket control, gave New York judges discretionary jurisdiction over claims by nonresidents against foreign corporations. ${ }^{68}$ Since this statute applied to all claims raised by nonresidents, including suits brought under New York law, the Supreme Court found that the New York statute did not dis-

61 Id. at 233-34.

62342 U.S. 359 (1952).

63 Id. at 363-64.

o4 Id. at 363 .

6B Id. (quoting Bailey v. Central Vt. Ry., 319 U.S. 350, 354 (1943)) (citing Brown v. Western Ry., 338 U.S. 294, 298-99 (1949)).

68 279 U.S. 377 (1929).

67 See id. at $382-83$.

68 See id. at 385 . 
criminate against federal claims. ${ }^{89}$ Similarly, in Missouri ex. rel. Southern Railway v. Mayfield, ${ }^{70}$ the Court concluded that a state court could refuse jurisdiction over a federal claim under the doctrine of forum non conveniens. ${ }^{71}$

\section{State Court Refusal to Grant Federal Remedies}

Once a state court has concurrent jurisdiction over the parties and events involved in a federal cause of action, the court appears obligated to provide a forum for the federal claim. However, at least one state court has argued that since state law does not permit awarding of attorney's fees, it need not hear federal claims brought pursuant to provisions such as section 1983 that include the awarding of attorney's fees as an "integral part" of the federal statutory scheme. ${ }^{72}$ In Spencer $v$. South Carolina Tax Commission, ${ }^{73}$ the Supreme Court of South Carolina declared that "[s]tate remedies for asserting rights may not be circumvented by invoking section 1983." "74 The court held that a state statute prohibiting the assessment of costs in the plaintiff's state law action excused the court from hearing the plaintiff's related federal claim. ${ }^{75}$ The decision exaggerates both the role that the availability of

${ }^{69}$ See id. at 387.

70340 U.S. 1 (1950).

71 See id. at 5. The Court held that a state may refuse to hear a federal claim "if in similar cases the State for reasons of local policy denies resort to its courts and enforces its policy impartially." Id. at 4 (citation omitted).

${ }^{2}$ See S. ReP. No. 1011, 94th Cong., 2d Sess. 5, reprinted in 1976 U.S. Code CoNG. \& AD. News 5908, 5912-13.

${ }_{73} 281$ S.C. 492 , 316 S.E.2d 386 (1984), affd, 105 S. Ct. 1859 (1985) (per curiam).

${ }^{74} I d$. at 497, 316 S.E.2d at 389 (citing Backus v. Chivilis, 236 Ga. 500, 505-06, 224 S.E.2d 370, 374-75 (1976)).

${ }^{75}$ Id. at 497,316 S.E.2d at 388-89. The decision in Spencer should, at most, be read as limited to its facts. The dispute dealt with a state tax statute. In 1937, Congress passed the Tax Injunction Act, 28 U.S.C. § 1341 (1982), which prohibits federal courts from granting injunctions in cases involving imposition of state taxes as long as "plain, speedy and efficient" relief is available through the state court system. Although the act concerns only injunctions, the Supreme Court has found that the principle of comity, which underlies section 1341, also requires prohibition of state tax suits in federal courts for refunds of unconstitutional taxes, see First Nat'l Bank v. Board of County Comm'rs, 264 U.S. 450, 456 (1924), declaratory judgments in state tax suits, see Great Lakes Co. v. Huffman, 319 U.S. 293 (1943); see also California v. Grace Brethren Church, 457 U.S. 393, 408 (1982) (holding that a district court did not have jurisdiction under the Tax Injunction Act to issue "a declaratory judgment holding state tax laws unconstitutional"), and damage suits against state tax officials under section 1983, see Fair Assessment in Real Estate Ass'n v. McNary, 454 U.S. 199 (1981). Since the Tax Injunction Act seeks to limit federal interference with the collection of state taxes, and reflects the assumption that state courts are unlikely to interfere, see S. REP. No. 1035, 75th Cong., 1st Sess. 1 (1937), and that the pay-under-protest remedies provided by states such as South Carolina are satisfactory, id., it can be ar- 
state remedies plays in determining state court jurisdiction over federal claims and the discretion that state courts have to refuse to provide federal remedies once jurisdiction has been established:

The failure of state law explicitly to authorize state courts to provide the remedies available under federal law does not justify a state court's refusal to hear a federal claim. The Court in Testa noted that "the obligation of states to enforce these federal laws is not lessened by reason of the form in which they are cast or the remedy which they provide." cause the state ordinarily does not extend a remedy available under a federal claim would conflict with the principles that obligate state courts to enforce federal claims. The line of cases from Claflin to Second Employers' Liability Cases to Testa supports the conclusion that state courts must treat most federal claims as if they arose from statutes enacted by the state's own legislature. When confronted with a federal cause of action that requests a certain remedy, a state judge should not ask: "Does existing state law link the remedy to a similar state cause of action?" Instead, the state judge should inquire: "Would I have the power to grant the remedy if state law had made it available for claims similar to the federal claim?"

Finally, a state court's limitation of concurrent jurisdiction to claims that seek remedies available under state law would inhibit the operation of federal statutes motivated by dissatisfaction with existing state remedies. ${ }^{77}$ For example, section 301(e) of the Labor Management Relations Act resulted in part from a belief among some members of Congress that state remedies against labor unions in contract disputes were inadequate. ${ }^{78}$ The Supreme Court has held that state courts have concurrent jurisdiction to hear claims under section $301(\mathrm{e}) .^{79}$ To

gued that section 1983, which Congress enacted prior to the Tax Injunction Act, should not be read to authorize interference with state procedures and remedies Congress subsequently deemed satisfactory when it passed the Tax Injunction Act. Since Spencer was affirmed per curiam, the Supreme Court did not indicate its reasons for endorsing the South Carolina decision. Any explanation other than deference to state tax procedures, however, would involve some measure of Court approval of the Spencer state court's problematic section 1983 and 1988 analysis, the flaws of which this section of the Comment discusses.

76330 U.S. at 391.

77 In the related context of determining the extent of governmental immunities, see Kreimer, The Source of Law in Civil Rights Actions: Some Old Light on Section 1988, 133 U. PA. L. REv. 601, 607 (1985) ("There is, moreover, some incongruity in suggesting that a statute adopted to redress a failure of existing legal remedies for violations of constitutional rights should be defined by the scope of those very remedies.") (footnote omitted).

${ }^{78}$ See Dowd, 368 U.S. at 510-13.

${ }^{79} I d$. at 506. 
limit state courts hearing such suits to state remedies would frustrate congressional intent.

Most of the state courts that have considered the issue have determined that the exercise of concurrent jurisdiction does not depend on the state remedies available for a state claim similar to the federal claim. For example, in Thompson v. Village of Hales Corners, ${ }^{80}$ the Supreme Court of Wisconsin found that a state law limiting the tort liability of municipalities did not bar actions in Wisconsin courts under section 1983:

[S]tate law cannot be used where its application would frustrate federal policies. The policy behind section 1983 civil rights actions is one of compensation for actual injury. Insofar as the state recovery ceiling prevents realization of that policy, it must give way. We conclude that the limitation on municipal liability set forth in [a state statute] has no application to a damage award under 42 U.S.C. $§ 1983 .^{81}$

The supreme courts of at least three other states have reached similar conclusions. $^{82}$

The United States Supreme Court has also declined to attach any jurisdictional significance to the availability of specified remedies under state law. In Sullivan v. Little Hunting Park, ${ }^{83}$ for example, the Court held that the injunctive relief provided by section 1988 could be granted in suits under 42 U.S.C. $\S 1982^{84}$ by any state court with equitable power. ${ }^{85}$ When the same question arose pursuant to a section 1983 claim in Martinez v. California, ${ }^{86}$ the Court observed:

“" 'Conduct by persons acting under color of state law which is wrongful under 42 U.S.C. $\S 1983$ or $\S 1985$ (3) cannot be immunized by state law. A construction of the federal statute which permitted a state immunity defense to have controlling effect would transmute a basic guarantee into an illusory promise; and the supremacy clause of the Constitution insures that the proper construction may be enforced." "s7

80 115 Wis. 2d 289, 340 N.W.2d 704 (1983).

81 Id. at 304,340 N.W.2d at 711.

82 See Coalition for Economic Survival v. Deukmejian, 171 Cal. App. 3d 954, 217 Cal. Rptr. 621 (1985); Thiboutot v. Maine, 405 A.2d 230 (Me. 1979), aff d, 448 U.S. 1 (1980); Gomez v. Board of Educ. 85 N.M. 708, 516 P.2d 679 (1973).

83396 U.S. 229 (1969).

8442 U.S.G. $\$ 1982$ (1982).

8s Sullivan, 396 U.S. at 238.

${ }^{86} 444$ U.S. 277 (1980).

${ }^{87}$ Id. at 284 n.8 (quoting Hampton v. Chicago, 484 F.2d 602 (7th Cir. 1973), 
A few months later, in Maine $v$. Thiboutot, ${ }^{88}$ the Court upheld a section 1988 award of attorney's fees in a section 1983 suit although Maine law made no provision for awarding fees or costs for similar state claims. The Court concluded in Thiboutot that "the fee provision is a part of the section 1983 remedy whether the action is brought in federal or state court." 89 Under the Martinez and Thiboutot decisions state remedies appear to be irrelevant in defining a state court's jurisdiction to hear section 1983 claims. ${ }^{90}$ Once a state court establishes jurisdiction over a federal claim, it may apply a federal remedy not available under state law. Under the Supreme Court's decision in Garrett $v$. Moore-McCormack Co., ${ }^{91}$ state courts are "bound to proceed in such manner that all the substantial rights of the parties under controlling federal law would be protected." section 1988 is considered essential to the enforcement of the substantive provisions of section $1983,{ }^{93}$ the two sections are effectively one statute that state courts must enforce in its entirety.

\section{Federal Abrogation of State Sovereign Immunity}

As the above section shows, state courts have concurrent jurisdiction to hear section 1983 suits; conflict with existing state law does not justify refusal to entertain a section 1983 suit. In addition, the obligation to hear section 1983 claims carries with it the obligation to enforce remedies provided in section 1988; the lack of availability of attorney's fees under similar state statutes does not excuse a state court's refusal of jurisdiction over section 1983 suits. Plaintiffs seeking injunctive relief and attorney's fees from a state must consider, however, the state's sovereign immunity. A state unwilling to submit to a section 1983 and section 1988 suit in its own courts may argue that whatever power

cert. denied, 415 U.S. 917 (1974) (quoting McLaughlin v. Tilendis, 398 F.2d 287, 290

(7th Cir. 1968))).

${ }_{88} 448$ U.S. 1 (1980).

${ }^{80}$ Id. at 11 .

80 But cf. supra note 75 (regarding the unavailability of injunctions in section 1983 suits challenging state taxes). A strong argument can be made, however, for requiring state courts to hear section 1983 suits for tax refunds. See Note, Section 1983 in State Court: A Remedy for Unconstitutional State Taxation, 95 YALE L.J. 414 (1985); see also Bung's Bar \& Grille, Inc. v. Township of Florence, 206 N.J. Super. 432, 457-62, 502 A.2d 1198, 1213-16 (1985) (awarding attorney's fees under section 1988 on the grounds that the Tax Injunction Act does not deprive state courts of jurisdiction over section 1983 tax suits).

92 317 U.S. 239 (1942) (involving a suit by a seaman in state court for damages under the federal Merchant Marine Act).

${ }^{92} I d$. at 245.

93 See S. REP. No. 1011, 94th Cong., 2d Sess. 5, reprinted in 1976 U.S. CoDE ConG. \& AD. News 5908, 5912-13. 
Congress has to empower state courts to hear claims against private parties and state government officers and entities, the relationship between a state government and its judiciary is entirely a matter of state concern. According to this argument, it would violate the central principle of sovereign immunity - a sovereign cannot be sued in its own court without its consent ${ }^{94}$ - for Congress to pass a law that forces a state to submit to the authority of its own courts against its will.

\section{A. Sovereign Immunity in State Courts: Constitutional Considerations}

A state's sovereign immunity is not absolute. For example, in Fitzpatrick v. Bitzer, ${ }^{95}$ the Supreme Court held without dissent that Congress has the power under the fourteenth amendment to provide for private suits against states on federal claims in federal court. ${ }^{98}$ Congress, however, can force a state court to hear a suit against the state only if it can require the state court to hear a federally created cause of action and can abrogate any sovereign immunity defense a state could otherwise raise in its own court.

The discussion in Part II clarifies that the congressional creation of a cause of action, unless accompanied by a vesting of exclusive jurisdiction in the federal courts, gives rise to an obligation of state courts to provide a forum for the federal claim. Under the Court's present interpretation of state sovereignty in Garcia v. San Antonio Metropolitan Transit Authority, ${ }^{97}$ such congressional action causes no constitutional problem, since state sovereignty concerns permeate the institutional influence of the states on Congress's decision to create a cause of action. ${ }^{98}$ Even under the more restrictive, and now rejected, standard established in National League of Cities $v$. Usery, ${ }^{98}$ the requirement that state

${ }^{94}$ See Wolcher, Sovereign Immunity and the Supremacy Clause: Damages Against States in Their Own Courts for Constitutional Violations, 69 CALrf. L. REv. 189,246 (1981).

9s 427 U.S. 445 (1976).

${ }^{98}$ See id. at 456. Justices Brennan and Stevens filed separate concurring opinions. Justice Brennan claimed that the eleventh amendment "bars only federal court suits against States by citizens of other states," id. at 457 , and that the states surrendered their common law sovereign immunity "at least insofar as the States granted Congress specifically enumerated powers," $i d$. at 458 (citation omitted). Justice Stevens asserted that imposition of a suit against the state could be justified because the eleventh amendment "does not bar an action against state officers enforcing an invalid statute," $i d$. at 459 (citing Ex parte Young, 209 U.S. 123, 159-60 (1908)), and because damages would not be awarded directly from state funds, see id. at 459-60 (distinguishing Edelman v. Jordan, 415 U.S. 651 (1974)).

${ }_{87} 105 \mathrm{~S}$. C. 1005 (1985).

88 See id. at 1018.

89 426 U.S. 833 (1976), overruled, Garcia v. San Antonio Metropolitan Transit 
courts exercise jurisdiction over a cause of action created by Congress probably would not interfere with a state's ability to structure "integral operations in areas of governmental functions." 100 In Federal Energy Regulatory Commission v. Mississippi [F.E.R.C. $],{ }^{101}$ the Supreme Court concluded that a statute mandating the resolution of disputes arising under a federal utility regulation statute by a state administrative tribunal did not violate state sovereignty. ${ }^{302}$ The Court found that "the statute and the implementing regulations simply require the Mississippi authorities to adjudicate disputes arising under the statute. Dispute resolution of this kind is the very type of activity customarily engaged in by the Mississippi Public Service Commission."103 The Court cited Testa $v$. Katt ${ }^{104}$ as instructive and controlling authority regarding the obligation of the Mississippi tribunal to hear the federal claim. ${ }^{105}$ Accordingly, before a court could declare congressional imposition of a cause of action on state courts unconstitutional, it would have to overturn Garcia and F.E.R.C., and abandon or distinguish the interpretation of the supremacy clause endorsed in Testa.

At first glance, the discussion in the preceding two paragraphs appears to dispose of the question of whether Congress can make a state liable in actions in its own courts. If under Testa and Garcia Congress can require state courts to hear federal claims, a state appears to have no basis for arguing that a state court may decline to hear a federal claim under which the state or its officers must answer to the state court. A state could justify such an argument only if its right to refuse to be called into its own courts against its will were recognized under the Constitution. ${ }^{108}$

\section{B. State Sovereign Immunity Beyond the Eleventh Amendment: A Search for a Constitutional Foundation}

Most discussions about the constitutionality of a state's sovereign immunity focus on the eleventh amendment, which provides that "the Judicial power of the United States shall not be construed to extend to any suit in law or equity, commenced or prosecuted against one of the United States by citizens of another state, or by citizens or subjects of

Auth., 105 S. Ct. 1005 (1985).

100 Id. at 852.

101456 U.S. 742 (1982).

102 See id. at 760-61.

$103 \mathrm{Id}$. at 760.

104330 U.S. 386 (1947).

105 See F.E.R.C., 456 U.S. at 760.

${ }_{106}$ See Field, The Eleventh Amendment and Other Sovereign Immunity Doctrines, 126 U. PA. L. REv. 515, 536-39 (1978). 
any foreign state." ${ }^{\mathbf{1 0 7}}$ However, the eleventh amendment is irrelevant in the context of suits against the state in state court, since it limits only federal court jurisdiction. While language in some cases supports a state's sovereign immunity in state courts under the eleventh amendment, ${ }^{108}$ Supreme Court justices on both sides of the current debate over the boundaries of the eleventh amendment ${ }^{109}$ generally agree that the amendment does not restrict the jurisdiction of state courts.

For example, in Maine v. Thiboutot ${ }^{\mathbf{1 1 0}}$ the Court held that state courts may award attorney's fees in section 1983 actions. ${ }^{111}$ Justice Brennan observed, "No Eleventh Amendment question is present, of course, where an action is brought in a state court since the Amendment, by its terms, restrains only ' $t$ ] he Judicial power of the United States." "112 While this comment by a leader of the fight to reduce the scope of the eleventh amendment ${ }^{113}$ might not constitute sufficient authority to render the eleventh amendment inapplicable to state court jurisdiction, Justice Powell, the author of two recent opinions defending the vitality of the eleventh amendment, concurs with Justice Brennan. In his majority opinions in both Pennhurst State School E Hospital $v$. Halderman ${ }^{114}$ and Atascadero State Hospital v. Scanlon, ${ }^{115}$ Justice Powell carefully limits his discussion of the eleventh amendment to its effects on suits against a state in federal court. ${ }^{116}$ A state court seeking constitutional justification for its right to refuse suits against the state

107 U.S. ConST. amend. XI.

${ }_{108}$ See Wolcher, supra note 94, at 235 \& n.192 (citing cases).

108 Green v. Mansour, 106 S. Gt. 423 (1985), Atascadero State Hosp. v. Scanlon, 105 S. Ct. 3142 (1985), and Pennhurst State School \& Hosp. v. Halderman, 465 U.S. 89 (1984), are recent 5-4 decisions concerning the scope of the eleventh amendment.

110448 U.S. 1 (1980).

111 See id. at $10-11$.

112 Id. at 9 n.7 (quoting U.S. ConST. amend. XI).

113 See, e.g., Green v. Mansour, 106 S. Ct. 423, 429 (1985) (Brennan, J., dissenting); Atascadero State Hosp. v. Scanlon, 105 S. Ct. 3142, 3150 (1985) (Brennan, J., dissenting); Pennhurst State School \& Hosp. v. Halderman, 465 U.S. 89, 125 (1984) (Brennan, J., dissenting); Employees v. Department of Pub. Health \& Welfare, 411 U.S. 279, 298 (1973) (Brennan, J., dissenting).

114465 U.S. 89 (1985).

118105 S. Ct. 3142 (1985).

118 See id. at 3147 ("[I]n order for a state statute or constitutional provision to constitute a waiver of Eleventh Amendment immunity, it must specify the State's intention to subject itself to suit in federal court.") (citation omitted); id. at $3146 \mathrm{n} .2$ ("The issue is not the general immunity of the States from private suit . . but merely the susceptibility of the States to suit before federal tribunals.' ") (quoting Employees v. Department of Pub. Health \& Welfare, 411 U.S. 279, 293-94 (1973) (Marshall, J., concurring)) (emphasis added in Atascadero); Pennhurst, 465 U.S. at 120 ("[The eleventh amendment] is a specific constitutional bar against hearing even federal claims that otherwise would be within the jurisdiction of the federal courts.") (citation omitted). 
cannot rely on the eleventh amendment.

At least one commentator has suggested the existence of an implied state's right to immunity from suit in its own court, ${ }^{117}$ and some language in the Court's opinions comports with this view. ${ }^{118} \mathrm{~A}$ proper evaluation of this somewhat nebulous claim requires closer examination of how the Constitution resolves the problem of subjecting the sovereign authority of the states to the sovereign authority of the federal government.

When the representatives of the individual states negotiated the terms of the Constitution, they represented entities that possessed all the characteristics of sovereign states, including sovereign immunity at common law. The issue of what powers the states retained following the ratification of the Constitution has sparked debate for almost two centuries. The federal government certainly assumed the role of sovereign over the new nation. There is also no doubt that the Constitution did not explicitly abrogate the states' immunity from suit in their own courts; even today a state court cannot compel its own state government to appear in court without the state government's consent or acquiescence. ${ }^{118}$ Questions remain, however, regarding the extent to which sovereign immunity survived. By its very nature a common law doctrine such as sovereign immunity is subject to alteration by the judiciary or the legislature of the sovereign, and the legislature can override unwanted judicial interpretations of the common law through statutes or constitutional amendments. Prior to 1789 , state legislatures were the ultimate guardians of the states' common law immunity. The ratification of the Constitution, however, subjected the states to a new sovereign's courts and a new sovereign's legislature. Since the sovereign can modify the common law, a state's immunity from suit without its consent would be subject to any alteration which Congress has power to legislate, unless the Constitution protects the state's immunity.

Since article I does not limit Congress's ability to diminish the states' sovereign immunity, any restriction on the federal government's power to subject a state to suit must emanate from article III, which defines the judicial power relinquished by the states to the federal government. Although article III addresses only the power of federal courts, the Constitutional Convention considered the issue of state sov-

117 See Wolcher, supra note 94, at 246-47; see also Field, supra note 106, at 517 (comparing a hypothetical constitutional source of state sovereign immunity with the unstated source of the federal government's sovereign immunity).

118 See Field, supra note 106, at 548 (citing cases).

119 See W. Keeton, D. Dobbs, R. Keeton \& D. Owen, Prosser and Keeton oN THE LAW OF ToRTs 1043 (5th ed. 1984). 
ereign immunity in adopting article III. ${ }^{120}$

Section 2 of article III states:

The judicial power shall extend to all Cases, in Law and Equity, arising under this Constitution, [and] the Laws of the United States ... ; - to Controversies to which the United States shall be a Party;-to Controversies between two or more States; - between a State and Citizens of another State;-between Gitizens of different States . . . and between a State, or the Citizens thereof, and foreign States, Citizens, or Subjects. ${ }^{121}$

Some delegates to the Constitutional Convention interpreted this language as preserving the states' sovereign immunity. In the Virginia debates, John Marshall focused on the "State and Citizens of another State" language:

I hope that no gentleman will think that a state will be called at the bar of the federal court. . . . It is not rational to suppose that the sovereign power should be dragged before a court. The intent is to enable states to recover claims of individuals residing in other states. I contend this construction is warranted by the words. But, say that, there will be partiality in it if a state cannot be defendant-if an individual cannot proceed to obtain a judgment against a state, though he may be sued by a state. It is necessary to be so, and cannot be avoided. ${ }^{122}$

Other delegates interpreted the same language as providing a right for citizens of one state to sue another state. For example, the impartiality of the Constitution impressed James Wilson, since it established "a tribunal where both [a state and a citizen] may stand on a just and equal footing." ${ }^{123}$ Some commentators, less enthralled with the prospect of a citizen suing a state in federal court, did not share Wilson's interpretation of article III. The New York convention recommended an amendment that would have provided that the Constitution "not be construed to authorize any suit to be brought against any state, in any manner."124 Such an amendment, if accepted, would have embodied

120 See Nowak, supra note 3, at 1422-30.

121 U.S. Const. art. III, § 2.

1223 The Debates in the Several State Conventions on the Adoption OF THE FEDERAL Constitution 555-56 (J. Elliot ed. 1836) [hereinafter Elliot's Debates].

${ }^{123} 2$ Elliot's DeBates, supra note 122, at 491.

124 Id. at 409. 
constitutional recognition of states' substantive sovereign immunity. The delegates did not adopt the New York amendment, however, indicating that they chose to deal with the issue of suits against the states as a jurisdictional, rather than a substantive, problem.

The furor surrounding the Supreme Court's decision in Chisholm v. Georgia ${ }^{125}$ lends support to the notion that only a state's immunity from suits brought by its own citizens in federal court enjoys constitutional protection. In Chisholm, the Supreme Court read article III literally and heard a case in which a South Garolina citizen sued the state of Georgia. ${ }^{128}$ Some judicial commentators, including the first Justice Harlan, considered Chisholm to interpret the Constitution correctly;, ${ }^{127}$ at least some states, however, did not anticipate the result in Chisholm when they surrendered their sovereignty in the Constitution. For example, the Georgia legislature enacted a provision specifying that anyone attempting to collect on the debts in Chisholm would be "guilty of a felony and shall suffer death, without benefit of clergy, by being hanged." 128 The third Congress, exercising a little more restraint, began the process of reversing the heresy of the court in Chisholm by constitutional amendment.

The Chisholm decision afforded the states a perfect opportunity to write into the Constitution an affirmative right not to be sued without their consent. Instead, they cast their disapproval of the Chisholm decision in jurisdictional language. While the language of the eleventh amendment repudiates the interpretation of article III in Chisholm, it does not convey an affirmative grant of sovereign immunity to the states. ${ }^{129}$ This is important, because a state court can justify a refusal to hear a federal claim against the state only if the power to subject the state to potential liability was constitutionally denied to the federal government. ${ }^{130}$ Article III and the eleventh amendment preclude any in-

\footnotetext{
1252 U.S. (2 Dall.) 419 (1793).

126 See id.

127 See Field, supra note 106, at 516 n.3.

128 See id. at 536 n.78.

129 See id. at 540-41.
}

130 Even if a state's sovereign immunity is of constitutional magnitude, such immunity might not extend to a state court's refusal to hear a suit under section 1983 and section 1988. Both provisions were enacted pursuant to section 5 of the fourteenth amendment, and the same reasoning that justified the abrogation of eleventh amendment immunity in federal court in Fitzpatrick and Hutto v. Finney, 437 U.S. 678 (1978), see Comment, Civil Rights Attorney Fees in Cases Resolved on State Pendent and Federal Statutory Grounds, 130 U. PA. L. Rev. 488 (1981), would appear to justify the abrogation of any constitutional sovereign immunity defense raised in state court. One commentator has observed that:

If there is an implied constitutional doctrine giving states sovereign immunity from monetary liability in their own courts, one would have expected 
trusion on sovereign immunity by the federal courts, but are silent as to the power of the federal legislature to abrogate a state's sovereign immunity in state courts.

\section{State Sovereign Immunity as a Common Law Doctrine}

Since state sovereign immunity began as a common law doctrine and neither article III nor the eleventh amendment grants the states an affirmative constitutional right to avoid being haled into court against their will, the right of states to refuse to defend suits brought without their consent apparently maintains common law status. Professor Field recognizes the common law status of state sovereign immunity in her article The Eleventh Amendment and Other Sovereign Immunity Doctrines. ${ }^{131}$ While Field's article focuses primarily on the basis for state sovereign immunity in federal courts, her analysis is useful in evaluating states' sovereign immunity in their own courts. ${ }^{\mathbf{1 3 2}}$

The language of article III and the wording of the eleventh amendment do not detract from a common law theory of substantive sovereign immunity. As previously mentioned, states' common laws are subject to alteration by both the state courts and the state legislatures. The subordination of state law to federal law by the supremacy clause also subjects the states' common law to alteration by Congress and the federal courts. In numerous instances, federal legislation has modified state common law doctrines. For example, in Dice v. Akron, Canton $\Xi^{\circ}$ Youngstown Railroad ${ }^{138}$ the Supreme Court found that Ohio's common law allocation of the determination of fraud to the judge must yield to the allocation to the jury endorsed in the Federal Employees Liability Act. Similarly, the common law prohibitions of suits against

the Court [in Maher v. Gagne, 448 U.S. 122 (1980)] to analyze whether Congress could constitutionally remove that immunity by enacting legislation under article I or any other portion of the Constitution. That it did not do so implies either that no such immunity doctrine exists, or that it is so clearly subject to congressional modification as not to warrant discussion.

Wolcher, supra note 94 , at 259 . This Comment argues that a state's right not to be sued in its own courts is not of constitutional magnitude.

131 Field, supra note 106, at 538.

132 See id. at 546. While Professor Field's analysis of the basis for sovereign immunity is in some ways even more limited than the analysis of Justice Brennan, who also advocates a common law theory of state sovereign immunity, see id. at 539 , her view comes closest to providing a coherent explanation for Justice Marshall's proposition in Employees v. Department of Pub. Health \& Welfare, 411 U.S. 279, (1973) adopted by Justice Powell in Atascadero, that state courts can hear federal suits barred from federal courts by the eleventh amendment. See supra note 115 and accompanying text.

1 ss 342 U.S. $359,362-64$ (1952). 
organizations such as labor unions in Charles Dowd Box Co. v. Courtney ${ }^{134}$ and suits awarding attorney's fees as in Maine $v$. Thiboutot ${ }^{\mathbf{1 3 5}}$ were deemed impotent in the face of conflicting federal statutes.

Under a common law theory of sovereign immunity, the state courts, the state legislatures, the federal courts, and Congress may limit a state's sovereign immunity. The state courts and the state legislatures are unlikely to restrict such immunity. The state legislature could reverse any state court abrogation of sovereign immunity, and, by definition, could not remove the state's immunity without its consent. A state need not rely on constitutional affirmation of sovereign immunity for protection from its own courts or legislature.

In contrast, a federal court holding a state liable would not be subject to correction by the state's legislature. The eleventh amendment was intended to prevent restriction of a state's sovereign immunity by federal courts. ${ }^{138}$ The grant of judicial authority to the federal courts in article III carefully excludes cases between a state and the state's own citizens in which a federal court could modify the state's sovereign immunity. The eleventh amendment promptly eliminated the power extended to the federal judiciary in Chisholm to hear disputes between a state and citizens of another state. ${ }^{137}$ Functionally, the jurisdictional language in article III and the eleventh amendment eliminate the authority of the federal courts to meddle with a state's sovereign immunity on their own initiative.

No such elaborate scheme of constitutional protection shields a state's sovereignty from interference by the federal legislature. ${ }^{138}$ If the Constitution had been intended to insulate a state's sovereign immunity from any federal modification, the delegates to the Constitutional Convention would have limited Congress's powers as the most effective means of creating such protection. The Constitution, however, reflects an assumption that the federal and state legislatures share substantially similar interests. Under this view, the principle of federalism described by the Court in Second Employers' Liability Cases ("[w] hen Congress, in the exertion of the power confided to it by the Constitution [acts], it [speaks] for all the people and all the States, and thereby establish[es] a policy for all") ${ }^{\mathbf{1 3 9}}$ results from the mutual interests of the state and

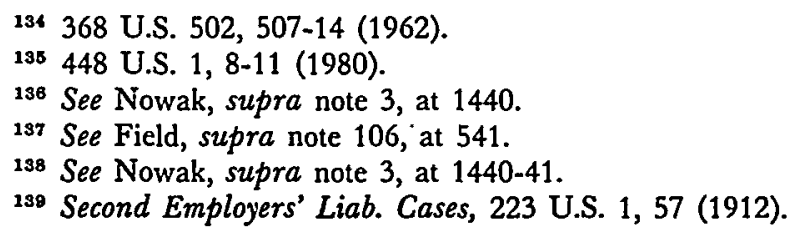


federal governments rather than from federal fiat. The Framers of the Constitution, who represented the states, may have never anticipated a situation in which Congress would pass legislation authorizing suits against states for reasons that would not have persuaded a state legislature to surrender its immunity. ${ }^{140}$

Viewing the Constitution as intended to protect a state's common law sovereign immunity bolsters Justice Blackmun's argument in Garcia v. San Antonio Metropolitan Transit Authority that institutional considerations in the federal system, rather than explicit guarantees in the text of the Constitution, protect state sovereignty. ${ }^{141}$ While it was thought necessary to restrain the power of the federal judiciary to limit state sovereignty, the federal legislature, which Madison assured would "partake sufficiently of the spirit [of States] to be disinclined to invade the rights of the individual States or the prerogatives of their governments," 142 was not similarly restrained. The Framers evidently saw no need to protect a state's sovereign immunity from infringement by the branch of the federal government considered sensitive to state interests.

The institutional influence accorded to the states in the Constitution appears calculated to ensure that the federal legislature remains sympathetic to state concerns. As the Gourt noted in Garcia:

The Framers thus gave the States a role in the selection of both the Executive and Legislative Branches of the Federal Government. The States were vested with indirect influence over the House of Representatives and the Presidency by their control of electoral qualifications and their role in presidential elections. U.S. Const., Art. I \& 2, and Art. II, § 1. They were given more direct influence in the Senate, where each State received equal representation and each Senator was to be selected by the legislature of his State. Art. I, $\S 3$. The significance attached to the States' equal representation in the Senate is underscored by the prohibition of any constitutional amendment divesting a State of equal representation without the State's consent. Art. V. ${ }^{143}$

In the context of state sovereign immunity, the jurisdictional wall erected by article III and the eleventh amendment added to the list of constitutional provisions that ensure the institutional influence of the

140 See Nowak, supra note 3, at 1441. (1985)

141 See Garcia v. San Antonio Metro. Transit Auth., 105 S. Ct. 1005, 1016-19

${ }_{142}$ The Federal.ist No. 46, at 332 (J. Madison) (B. Wright ed. 1961).

143 Garcia v. San Antonio Metro. Transit Auth., 105 S. Ct. 1005, 1018 (1985). 
states. While subsequent constitutional amendments have diluted the states' institutional influences, ${ }^{144}$ states' sovereignty was intact at the time of the Constitutional Convention, and additional factors suggested that the federal government would not attempt to interfere with the states' sovereignty. The Constitution was drafted by delegates chosen by the states, and would initially be interpreted by these same state-selected representatives when they became the first presidents, legislators and judges of the new republic. The legislative branch, composed of senators selected by the state legislatures and representatives enjoying terms sufficiently short to allow frequent reassessment by the electorate, would not seriously threaten state sovereignty, as evidenced by its reaction to the Chisholm decision. When the federal judiciary managed to hold a state liable without its consent, the third Congress intervened by drafting the eleventh amendment, which was then sent to state legislatures for ratification.

\section{Congressional Intent to Abrogate State Sovereign Immunity: Sections 1983 and 1988}

For many years, the federal government's institutional sensitivity to state sovereignty protected the states' common law immunity from congressional interference. Not until after the Civil War and the proposal of the fourteenth amendment did Congress recognize a need to restrain state sovereignty explicitly. ${ }^{145}$

Even under the broad mandate of the fourteenth amendment, Congress exercised with discretion its power to destroy state sovereignty. Perhaps the best example of Congress's restraint is found in the legislative history of the Civil Rights Acts of 1871, the forerunner of 42 U.S.C. $\S 1983{ }^{146}$ Whether Congress intended the word "person" in the statute to include or exclude state governments has been forever lost due to the passage of time and conflicting interpretations by scholars and judges predisposed to find support for a particular position. ${ }^{147} \mathrm{Sec}-$ tion 1983, however, has been consistently interpreted as not authorizing

144 For example, the seventeenth amendment to the Constitution established the popular election of senators. See U.S. ConST. amend. XVII.

145 See Nowak, supra note 3, at 1455, 1456 n.208.

148 See 42 U.S.C. $\$ 1983$ (1982).

167 In his concurrence in Quern v. Jordan, 440 U.S. 332 (1979), Justice Brennan recognized the subjectivity of commentators on section 1983 when he remarked: "The Court today pronounces its conclusion in dicta by avoiding such evidence. It chooses to hear, in the eloquent and pointed legislative history of section 1983, only 'silence.' Such silence is in fact deafening to those who have ears to listen." Id. at 365 (Brennan, J., concurring) (emphasis added). 
suits against a state without the state's consent. ${ }^{148}$ Although Congress has amended other laws to allow for suits against a state, ${ }^{148}$ it has allowed the existing judicial interpretation of section 1983 to stand. ${ }^{\mathbf{1 5 0}}$

The legislative history of the Civil Rights Attorney's Fee Awards Act of 1976, however, is not ambiguous. The Senate report states explicitly that Congress anticipated the charging of attorney's fees against state governments:

[D]efendants in these cases are often State or local bodies or State or local officials. In such cases it is intended that the attorneys' fees, like other items of costs, will be collected either directly from the official, in his official capacity, from funds of his agency or under his control, or from the State or local government (whether or not the agency or government is a named party). ${ }^{151}$

In Hutto v. Finney, the Supreme Court held that fee awards could be made against states in federal court, ${ }^{\mathbf{1 5 2}}$ abrogating both the express jurisdictional immunity provided by the eleventh amendment and any common law substantive immunity that survived the ratification of the Constitution. ${ }^{183}$

The abrogation of the state's sovereignty recognized in Hutto binds the states as if it were accomplished by their own legislatures. Under Second Employers' Liability Cases, ${ }^{154}$ Testa $v$. Katt ${ }^{155}$ and the supremacy clause, the states are obligated to hear claims under section 1988 as if such claims were raised under a state law. ${ }^{158}$ When Congress amended section 1988 to provide for attorney's fees, it intended to waive the state's immunity to the extent necessary to allow reasonable attorney's fees for a prevailing plaintiff in a suit under section 1983. Therefore, a state court confronted with a valid claim for relief under section 1983 involving an assessment of attorney's fees to be paid out of the state treasury has no constitutional right to refuse to hear the suit

148 See id. at 341-43.

149 See Fitzpatrick, 427 U.S. at 447-48 (describing the 1972 amendments to the Civil Rights Act of 1964,42 U.S.C. $\$ 2000 \mathrm{e}-2$ (1982)).

150 See Nowak, supra note 3 , at 1422 n.61 (citing failed legislative attempts to amend section 1983).

${ }^{151}$ S. REP. No. 1011, 94th Cong., 2d Sess. 5, reprinted in 1976 U.S. CodE Cong. \& AD. NEws 5908, 5913.

152437 U.S. 678, 693-700 (1978).

153 See Wolcher, supra note 94 , at 259.

154223 U.S. 1 (1912).

155330 U.S. 386 (1947).

156 See Claflin v. Houseman, 93 U.S. 130, 136 (1876) ("The laws of the United States are laws in the several States, and just as much binding on the citizens and courts thereof as the State laws are."). 
on the grounds that only a state legislature may subject the state to liability in its own courts.

\section{CoNCLUSION}

This Comment argues that as long as state courts have concurrent jurisdiction over a federal cause of action, they must enforce the rights and apply the remedies provided by the federal statute, even if these rights and remedies conflict with those available under existing state law. A state court is empowered to provide a forum for section 1983 and state law claims that have been deprived of a common forum by the Pennhurst decision, and cannot refuse to hear such claims despite the fact that the court could not award attorney's fees under the state's own laws. While some state judges may worry that mandatory state court jurisdiction will cause a deluge of frivolous section 1983 claims brought solely to create eligibility for fee awards, they cannot address this problem by closing the courthouse door to section 1983 suits. ${ }^{107}$

157 State courts are able to deny fee awards in suits predicated on meritless claims. One state court has observed,

To allow attorney's fees under section 1988 to parties who assert meritless

federal claims along with valid state claims would effectively abrogate the American Rule [of each party paying its own attorney's fees]. Any person with a claim founded in state law against a state or its subdivisions would have every incentive to interject a section 1983 claim into the action, regardless of its validity.

Jackson v. Inhabitants of Searsport, 456 A.2d 852, 856 (Me. 1983). In Jackson the plaintiff prevailed on the ground that the defendant violated state law by failing to follow state procedures that did not violate the fourteenth amendment. The court ruled that the plaintiff's section 1983 claim was therefore insubstantial. For other examples of state courts refusing to award attorney's fees on the ground that plaintiff's section 1983 claim was insubstantial, see County Executive of Prince George's County v. Doe, 300 Md. 445, 479 A.2d 352 (1984), and Brown v. Hornbeck, 54 Md. App. 404, 458 A.2d 900 (1983). 
